\title{
www.czasopisma.pan.pl \\ Analysis of the Possibility of Using Dynamic Methods for Assessment of Investment Projects in the Domestic Foundry Industry
}

\author{
J. Szymszal ${ }^{\mathrm{a} *}$, T. Lis ${ }^{\mathrm{a}}$, B. Gajdzik ${ }^{\mathrm{a}}$, J. Klis ${ }^{\mathrm{b}}$ \\ ${ }^{a}$ Department of Production Engineering, Silesian University of Technology, Krasińskiego 8, 40-019 Katowice, Poland \\ ${ }^{\mathrm{b}}$ Centrostal Górnośląski sp. z o.o., Stalowa 1, 40-610 Katowice, Poland \\ *Corresponding author: E-mail address: jan.szymszal@polsl.pl
}

Received 30.04 2014; accepted in revised form 15.05.2014

\begin{abstract}
A comparative analysis involving the evaluation of the effectiveness of investment projects can be based on various rules indicating selection of the most favorable decisions. The dynamic methods for assessment of investment projects discussed in this article, which consider the possibility of modifying the predetermined investment options, are quite complex and difficult to implement. They are used both in the construction phase of the new company, as well as in its subsequent modernization. The assessments should be characterized by a high coefficient of the economic efficiency. The, observed in practice, high dynamic variability of both the external and internal conditions under which the company operates is the reason why in the process of calculating the economic efficiency of investment projects, there is a significant number of random parameters affected by high uncertainty and risk. Investments in the metallurgical industry are characterized by a relatively long cycle of implementation and operation. These are capital-intensive projects and often mistakenly taken investment decisions end in failure of the investment project and, consequently, in the collapse of the company. In addition, the applied methods of risk assessment of investment projects, especially the dynamic ones, should be fully understood by managerial staff and constitute an easy to use, yet accurate tool for improving the efficiency of the company.
\end{abstract}

Keywords: Computer-aided foundry production, Dynamic methods for assessment of investment projects, Efficiency calculus

\section{Introduction}

A compilation of decisions related to the development of each company is divided into two main groups, namely [1-4]:

1. Area of decision-making used to accept or reject the investment project. This is an area called the decision-making calculus of relative efficiency of investment projects.

2. Area associated with the decision-making process of selecting one of the plurality of projects developed. This area is called the decision-making calculus of the absolute efficiency of investment projects.
A condition necessary for the proper functioning of enterprises and their development in the market is, in addition to the current effective management, the assimilation by managers of the skill to make optimal decisions related to further development of these enterprises. These actions can be associated with different areas of the foundry business activity, such as $[3,4]$ :

- measurable reduction in the cost of the company operation,

- improving the quality of production and introducing favorable changes in the structure of manufactured products,

- positive changes related with production volume,

- positive changes in the supplies, mainly the verification of existing sources of supply and preferred trends in the sales 
market,

- exploring the possibility of investing own capital outside the parent company.

The main division of investment projects implemented by economic entities includes the following types [3-6]:

- Strategic - the main goal is to protect the company against the effects of competition and consequently strengthen its market position.

- Development - the main goal is to increase the company's production potential, e.g. through introduction of new products into production, to significantly raise the productivity of own facilities, to develop and expand the sales network, etc.

- Modernization - the main goal is to reduce the cost directly associated with the production process, i.e. with the manufacture of final products.

- Replacement - the main goal is to reduce the cost associated with continuous and dynamic process of aging of own fixed assets; the ultimate goal is to replace the worn out or obsolete assets with new ones.

- Innovative - associated with modifications introduced to products already manufactured.

\section{Description of the problem}

Reference literature [1-6] emphasizes the fact that the decision-making procedures by which the domestic foundry industry can implement the investment projects described previously are often difficult and complicated. As a result of the performed procedure, an investment project (plan) arises which is a collection of documents necessary to take a decision relating to a specific material scope of the investment project.

Currently, frequently, in the complicated process of selecting investment options, dynamic methods are used. As the practical experience shows, these methods are difficult to understand by ordinary managers and sometimes require complex computations. Contrary to static methods, the dynamic methods use in the assessment of investment projects the size of the, extended in time, expected proceeds and expenses associated with the investment project assessed. One uses for this purpose so called discounting, which allows for standardization, that is, enables a comparison of both inputs and outcomes, which are implemented in different periods of time [2-4].

By using dynamic (discount) methods in the account of the profitability of investment project or development project it is possible to include the entire period of the project life, that is, the time of execution and subsequent operation. This considerably increases the accuracy and precision in assessing the profitability of projects. The use of these methods also imposes the need for a fairly accurate estimate of revenue and expenditure during the period of the investment account, which may be subject to increasing uncertainty of the prediction error of the market situation.

\section{Research method}

As part of own studies, a variety of dynamic methods have been used which serve the assessment and analysis of specific investment projects implemented recently by the domestic foundry industry.

\subsection{The method based on the net present value of the project - NPV}

In 2006, the Board of a large Foundry considered the advisability of undertaking an investment project related to building and furnishing a new mechanical fettling plant of predetermined output. The expected construction period, starting in 2006, lasted two years, and intended life (without repairs) six consecutive years, that is, until 2013, inclusive. Figure 1 shows the size of the investment during the construction period (cells $\mathrm{C} 3: \mathrm{C} 4)$, the volume of expenses involved in production activities carried out in the newly created mechanical fettling plant (cells D5:D10), and revenues in subsequent years of operation of the plant (cells E5:E10). The estimated cash flow (cells F3:F10) can predict the resulting high profitability of the investment project. However, to assess the actual profitability of the project, it was necessary to make the discounted cash flow analysis.

Accurate financial analysis of the referenced investment project showed that the funds for its financing came in $38 \%$ (cell C13) from the investor's own resources (i.e. from the Foundry) and in $62 \%$ (cell $\mathrm{C} 14$ ) from bank loans, where the agreed bank interest rate was $27 \%$ (cell $\mathrm{C} 15)$.

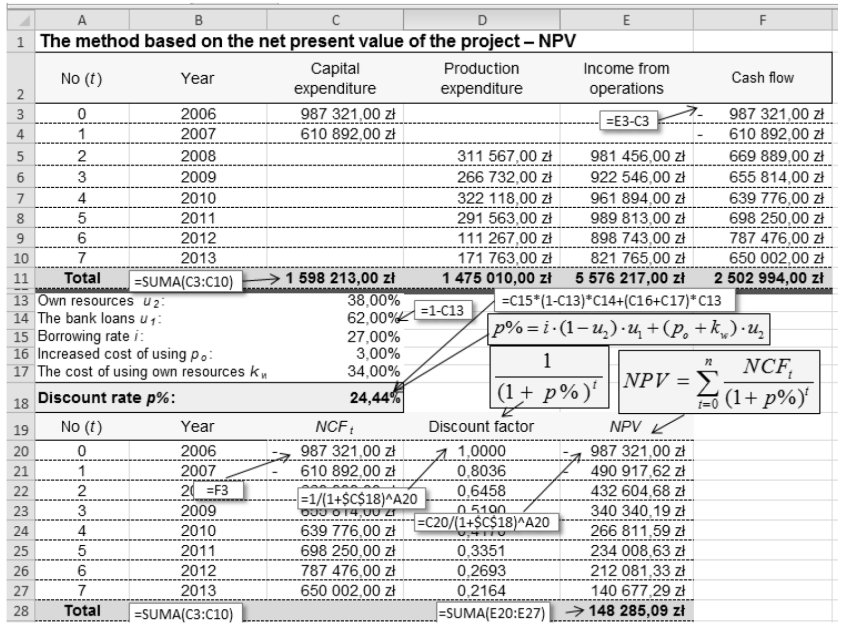

Fig. 1. Results of evaluation of the investment project of mechanical fettling plant based on net present value (own data)

The Foundry, on account of the risk, increased the cost of the use of equity by $3 \%$ (cell C16), while the cost of using the equity not covered by the risk was estimated at $34 \%$ (cell C17). In the first stage of the assessment, an estimate was made on the cost of capital, which in the next stage of evaluation was used as a discount rate in calculations of the NPV, the value of which amounted to $24.44 \%$ (cell C18). Then an estimate was made on 
the discount factor in the subsequent years of the calculation period (cells D20:D27) and discounted cash inflows size (cells E20:E27) obtained within the framework of the investment project. The total of the discounted net cash flows (cell E28) was only 148285 PLN, and because the value was positive, the project was considered worthwhile to implement. As it is implied, in subsequent years of operation the mechanical fettling plant should already bring much more tangible benefits to capital.

\subsection{The method based on the value of the internal rate of return - IRR}

In reference literature [1-6], the concept of internal rate of return - IRR means the value of the following ratio obtained from linear interpolation:

$$
I R R=r_{1}+\frac{P V\left(r_{2}-r_{1}\right)}{P V+|N V|}
$$

where:

IRR - internal rate of return,

$r_{1}$ - the value of the interest rate for which the NPV is positive, $r_{2}$ - the value of the interest rate for which the NPV is negative, $\mathrm{PV}$ - the NPV calculated for $\mathrm{r}_{1}$,

$\mathrm{NV}$ - the NPV calculated for $\mathrm{r}_{2}$.

One of the selected Foundries making castings for the automotive industry is planning an investment project involving the construction and commissioning of heat treatment department. Data related to the size of net cash flows are shown in Figure 2 (cells B5:B15).

\begin{tabular}{|c|c|c|c|c|c|c|}
\hline 4 & A & B & c & D & $\mathrm{E}$ & $\mathrm{F}$ \\
\hline 1 & \multicolumn{6}{|c|}{ The method based on the value of the internal rate of return - IRR } \\
\hline 2 & \multicolumn{2}{|c|}{ Enter the value r1: } & $14 \%$ & $\frac{1}{\left(1+r_{1}\right)^{n}}$ & $\frac{1}{\left(1+r_{2}\right)^{n}}$ & $1 /(1+\$ C \$ 3)^{\wedge} \$ A 5$ \\
\hline \multirow[b]{2}{*}{4} & \multicolumn{2}{|c|}{ Enter the value r2: } & $15 \%$ & \multicolumn{2}{|c|}{$=1 /(1+\$ C \$ 2)^{\wedge} \$ A 5$} & \multirow[b]{2}{*}{$\begin{array}{l}\text { NPV - Negative } \\
\text { value }\end{array}$} \\
\hline & No of year $(n)$ & Net cash flow & $\begin{array}{l}\text { Discount factor } \\
\text { calculated for }\end{array}$ & $\begin{array}{l}\text { NPV - Positive } \\
\text { value }\end{array}$ & $\begin{array}{l}\text { Discount täctor } \\
\text { calculated for } / 2\end{array}$ & \\
\hline 5 & 0 & $501930,00 \mathrm{PLN}$ & $1,0000 \downarrow$ & $501930,00 \mathrm{PLN}$ & 1,0000 & 501930,00 PLN \\
\hline 6 & 1 & $760500,00 \mathrm{PLN}$ & 0,8772 & 667105,26 PLN & 0,8696 & 661304,35 PLN \\
\hline 7 & 2 & 81373,50 PLN & 0,7695 & 62614,27 PLN & 0,7561 & $-61530,06$ PLN \\
\hline 8 & 3 & $266935,50 \mathrm{PLN}$ & 0,6750 & $180173,86 \mathrm{PLN}$ & \multirow{2}{*}{$=\mathrm{BS}^{*} \mathrm{C} C 55 \frac{5}{18}=\mathrm{B}$} & $175514,42 \mathrm{PLN}$ \\
\hline 9 & 4 & $340704,00 \mathrm{PLN}$ & 0,5921 & $201724,12 \mathrm{PL}$ & & 594798,62 PLN \\
\hline 10 & 5 & 497367,00 PLN & 0,5194 & 258316,83 PLN & \multirow{2}{*}{$\frac{0,4972}{0,4323}$} & 247279,30 PLN \\
\hline 11 & 6 & 532350,00 PLN & 0,4556 & $242531,50 \mathrm{PLN}$ & & 230149,60 PLN \\
\hline 12 & 7 & $173394,00 \mathrm{PLN}$ & 0,3996 & \multirow{2}{*}{$\begin{aligned} 69294,71 \mathrm{PLN} \\
114,104.87 \mathrm{PLN}\end{aligned}$} & 0,3759 & $65185,23 \mathrm{PLN}$ \\
\hline 13 & 8 & 325494,00 PLN & 0,3506 & & 0,3269 & 106404,57 PLN \\
\hline 14 & 9 & 389694,00 PLN & 0,3075 & $119834,00 \mathrm{PLN}$ & 0,2843 & 110775,36 PLN \\
\hline 15 & 10 & $346894,00 \mathrm{PLN}$ & 0,2697 & 93572,51 PLN & 0,2472 & 85746,89 PLN \\
\hline 16 & Total & $1529029,00 \mathrm{RLN}$ & & 47 902,87 PLN & & 8910,42 PLN \\
\hline \multirow[t]{2}{*}{17} & & & & \multirow{3}{*}{$I R R=r_{1}+$} & \multirow{3}{*}{$\frac{P V\left(r_{2}-r_{1}\right)}{P V+|N V|}$} & \\
\hline & \multirow{2}{*}{\multicolumn{2}{|c|}{\begin{tabular}{|l|} 
Internal rate of return: IRR: \\
$==\mathrm{C} 2+\left(\mathrm{D} 16^{*}(\mathrm{C} 3-\mathrm{C} 2)\right) /(\mathrm{D} 16+\mathrm{MO})$
\end{tabular}}} & $\rightarrow^{14,84 \%}<$ & & & \\
\hline 19 & & & t.LICZBY(F16)) & & & \\
\hline
\end{tabular}

Fig. 2. NPV estimate for the internal rate of return of $10 \%$ and $20 \%$ for the examined investment project (own data)

At the beginning, levels of interest rates, for which the NPV should have a positive value $\mathrm{r}_{1}=10 \%$ (cell $\mathrm{C} 2$ ) and negative value $r_{2}=20 \%$ (cell C3), were calculated. For thus adopted levels of interest rates, the value of the internal rate of return (cell C18) was estimated to be at a level of $15.73 \%$.

Then, using Solver optimization tool, the objective function was set as a minimum internal rate of return, by defining constraints $\mathrm{PV} \geq 1$ (cell D16) and $\mathrm{NV} \leq-1$ (cell D16) and setting the decision variables as $r_{1}$ and $r_{2}$ (cells $\mathrm{C} 2$ and $\mathrm{C} 3$ ).

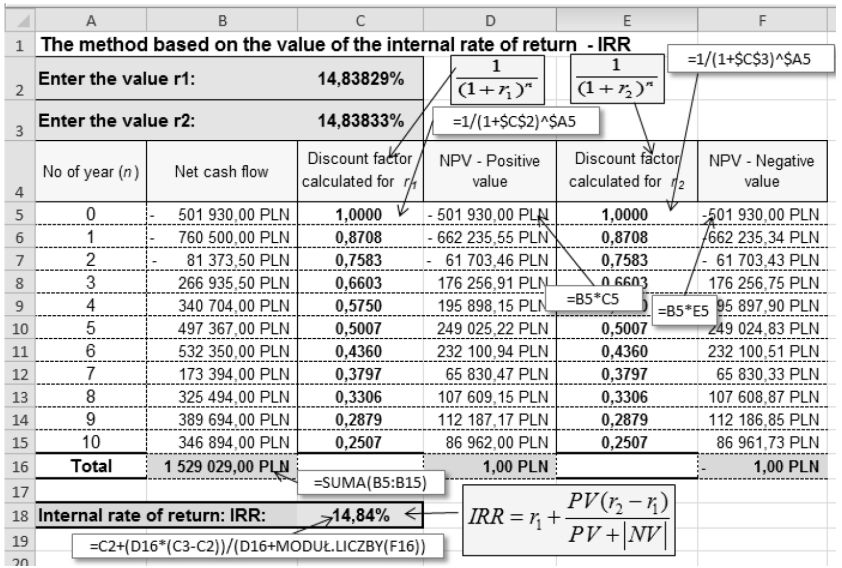

Fig. 3. The estimated boundary internal rate of return for the investment project (own data)

The resulting solution (Fig. 3) shows that if the investor set a limit rate of return at a level higher than $14.84 \%$, the investment project should be rejected, but if the level was less than $14.84 \%$, the project should be accepted.

\subsection{The method based on profitability index - PI}

Another method for evaluation and analysis of investment projects is the method based on profitability index, which in the reference literature is often called an indicator of profitability. This index is calculated as a total discounted positive cash flowto-total discounted negative cash flow ratio:

$P I=\frac{\sum_{t=0}^{n} \frac{C I F_{t}}{(1+p \%)^{t}}}{\sum_{t=0}^{n} \frac{C O F_{t}}{(1+p \%)^{t}}}$

where:

$\mathrm{COF}_{\mathrm{t}}$ - the size of the negative cash flows in the year, $\mathrm{CIF}_{\mathrm{t}}$ - the size of the positive cash flows in the year, $\mathrm{p} \%$ - the discount rate used by the company.

For implementation, it is advisable to accept the investment projects for which the value of $P I$ is higher than unity, and as a basis for selecting the most cost-effective investment project among several pending, the maximum value of the profitability index PI should be adopted.

A large Foundry producing cast fixtures and fittings for construction industry has prepared for the next year three alternative investment projects to build new work stands for the machining of castings. The results of a detailed estimate of the cash flow streams are shown in Figure 4 (cells B6:D12). In carrying out any of the selected investment projects, the 
management of the Foundry assumed that the amount invested in the project should not exceed 120000 PLN, with the expected minimum $21 \%$ rate of return (cell D2) .

In the first stage of selection of the most economically viable alternative investment project, the values of NPV were calculated for each proposed project using the expected minimum growth rate (cells E6:E12, D6:D12 and E6:E12). The total NPV for all the examined investment projects (cells E13, F13 and G13) includes only the components that are characterized by a positive value of net cash flows. Then, for each of the examined investment projects of the casting machining stand, the value of profitability index (cells D15, D16 and D17) was calculated according to equation (2).

Based on the obtained values of the profitability index, for further implementation, the first to be accepted was PROJECT II. For this project, also the NPV gave the highest values.

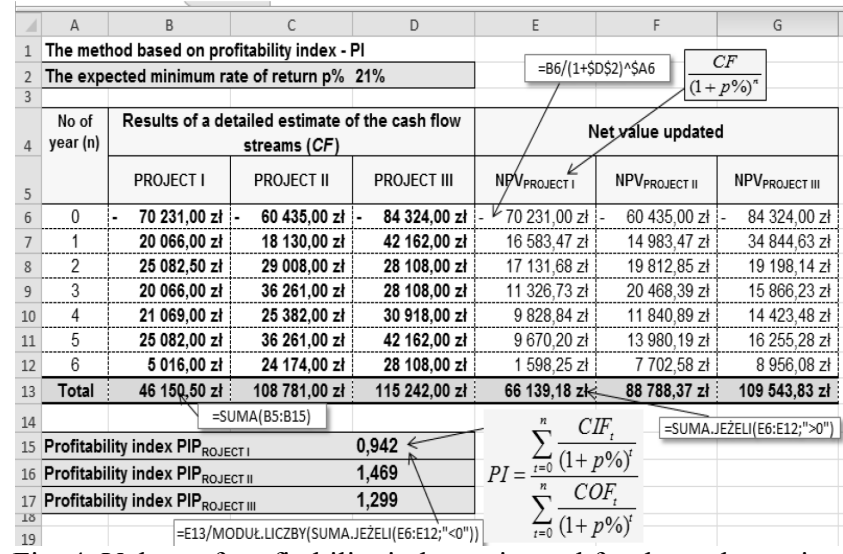

Fig. 4. Values of profitability index estimated for three alternative investment projects of the casting machining stand (own data)

On the relevance of the decision which of the investment projects should be taken for further implementation depends mostly the perspective level of competitiveness and efficiency of the company, as well as its ability to generate profits and market share.

\section{Conclusions and recommendations}

Detailed analysis of the use of the methods presented allowed drawing the following conclusions and recommendations:

- The use of a method based on the net present value NPV requires accurate estimation of the cost of the use of capital, which mainly depends on the source of project financing (equity or foreign capital), interest rate on credit, the size of the income tax, the level of profitability achieved in an alternative placement of own funds and the amount of risk associated with investing directly in the selected investment market.

- Methods for evaluation of investment projects based on the internal rate of return can be successfully used to assess individual projects and to select the most viable options from a number of alternatives. In this case, the guiding factor should be the maximum value of IRR, paying attention to the fact that increasing the accuracy of the assessment of the IRR can be achieved by reducing the difference between $r_{1}$ and $r_{2}$ (equation 1).

- In cases where there is more than one IRR (e.g. the implementation of investment projects in the field of metallurgy that require big expenses both at the start and end of the investment project life), the effectiveness of investment projects should be carried out basing on the net present value NPV.

- The criteria for selection of the investment project based on the profitability index PI are particularly recommended for application in the case of limited financial possibilities of foundry plants and only for those projects that have a positive net present value, since negative NPV eliminates the investment project.

- Readable and reliable assessment of the effectiveness of investment projects based on dynamic methods can be successfully implemented by managers using generally available Excel spreadsheet.

\section{References}

[1] Chapman, Ch., Ward, S. (1997). Project Risk Management. Chichester: John Wiley\&Sons.

[2] Ostrowska, E. (2002). The investment risk. Gdańsk: Ed. University of Gdansk. (in Polish).

[3] Sobczyk, M. (2003). Financial Mathematics. Warszawa: Ed. Placet. (in Polish).

[4] Marcinek, K. (2000). The risk of investment projects. Katowice: Ed. University of Economics. (in Polish).

[5] Bławat, F. (2001). Economic Analysis. Gdańsk: Ed. Gdansk University of Technology. (in Polish).

[6] Krawczyk, St. (2001). Quantitative methods in planning of the company's activity. Warszawa: Ed. C.H. Beck. (in Polish). 